\title{
Analyzing work organization on livestock farm by the Work Assessment Method
}

\author{
Sylvie Cournut ${ }^{1}$ (D) - Sophie Chauvat ${ }^{2} \cdot$ Pastora Correa $^{3} \cdot$ Joel Carneiro Dos Santos Filho ${ }^{4}$. Francisco Diéguez ${ }^{5}$. \\ Nathalie Hostiou ${ }^{1}$. Duy Khanh Pham ${ }^{6} \cdot$ Gérard Servière $^{7} \cdot$ Mohammed Taher Sraïri $^{8}$. Amélie Turlot ${ }^{9}$. \\ Benoît Dedieu ${ }^{10}$
}

Accepted: 13 September 2018 / Published online: 23 October 2018

(C) INRA and Springer-Verlag France SAS, part of Springer Nature 2018

\begin{abstract}
All over the world, farmers have to face up to increasing uncertainties (market and climate). They have to adapt their activity to the new contexts and challenges of livestock farming (producing more and better, and satisfying the expectations of society, consumers, and of downstream operators), while at the same time responding to their own expectations in terms of income, quality of life, and working conditions. In order to understand these changes and consider the future, work organization must be taken into account. The Work Assessment Method, developed by French livestock researchers, provides a framework able to capture work organization, taking into account the specifics of the livestock activity. Based on a comparative analysis of nine case studies that used the Work Assessment Method from six contrasted countries, this review (1) gives generic ideas on work organization indicators and their variation; (2) identifies four generic patterns of work organization which are not linked to the local context but marked by the workforce composition; (3) demonstrates that the relevance of the Work Assessment Method to tackle work issues, and its capacities to be adapted to a variety of livestock farming contexts throughout the world, is linked to the properties of its framework, which was developed by combining different disciplinary approaches; (4) highlights the principal limits of the method: lack of coordination with other dimensions of work (labor productivity; sense of the job), and limited characterization of the work organization flexibility; and (5) proposes some possibilities of change to better respond to the diversity of work situations and questions about work, and take better into account the evolutions of livestock farming systems.
\end{abstract}

Keywords Work organization $\cdot$ Liveability $\cdot$ Assessment method $\cdot$ Livestock farming systems $\cdot$ Labor

\section{Contents}

1. Introduction

2. Work Assessment Method: a brief presentation

2.1 A framework of work organization based on three principles

2.2 Methodological choices

Sylvie Cournut

sylvie.cournut@vetagro-sup.fr

1 Université Clermont Auvergne, AgroParisTech, INRA, Irstea, VetAgro Sup, UMR Territoires, 630170 Aubière, France

2 Institut de l'Elevage, 2 Place Pierre Viala, 34060 Montpellier Cedex 2, France

3 Facultad de Agronomía-EEFAS-UdelaR, Ruta 31. Km 21,5, Salto, Uruguay

4 Emater, Curitiba, Brazil
3. Comparative analysis of case studies

3.1 Presentation of the approach

3.2 Knowledge produced about work organization 3.2.1 Workforce configuration

3.2.2 The different tasks

5 Facultad de Veterinaria IPAV - UdelaR, Ruta 1, km 42,5, Libertad, San José, Uruguay

6 Rudec-Ipsard, 16 Thuy Khue, Tay Ho, Hanoï, Vietnam

7 Institut de l'Elevage, 9 Allée Pierre de Fermat, 63170 Aubière, France

8 Hassan II Agronomy and Veterinary Medicine Institute, P.O. Box 6202, Rabat, Morocco

9 Centre Wallon de Recherches Agronomiques, 8 rue de Liroux, 5030 Gembloux, Belgium

10 Inra Département SAD, Theix, 63122 Saint Genes Champanelle, France 
3.2.3 Structure of the work time and time available over time

3.2.4 Assessment of the organization: efficiency and flexibility

3.3 Generic patterns of work organization

4. Discussion of the method

4.1 Specific features of the framework

4.2 Adaptability and limits of the method

4.2.1 What about other work dimensions

4.2.2 Taking into account tasks

4.2.3 Taking into account workers

4.2.4 Flexibility assessment

4.3 Contributions to advice, research and training

5. Conclusions

Declaration on conflict of interest

References

\section{Introduction}

All over the world, work is at the heart of the issue of change in livestock farming. In Europe, and more generally in the OECD countries, livestock farming is marked by the increasing size of farms, combined with a decrease in the family workforce and the development of labor off the farm (Madelrieux and Dedieu 2008; Dedieu and Servière 2012). In the southern countries, the structural changes are different, with the continuation of small family farms, which are diversifying, and the development of large industrial farms (Purseigle et al. 2013; Contzen and Forney 2017). Everywhere, farmers have to face up to increasing uncertainties (e.g., market and climate). They have to adapt their activity to the new contexts and challenges of livestock farming (e.g., producing more and better, and satisfying the expectations of society, consumers, and downstream operators), while at the same time responding to their own expectations in terms of income, quality of life, and working conditions (Darnhofer et al. 2012). These structural, economic, and sociological changes affect the technical and social components of livestock farming systems (Gibon et al. 1999), especially via the impact of the changes on work organization (Madelrieux and Dedieu 2008; García-Martínez et al. 2009). Thus, work organization is a central element to be taken into account when considering the future of livestock farms.

There are different disciplines which deal with work and its organization on farms; Economics to answer questions about work duration and labor productivity (Bewley et al. 2001; O'Brien et al. 2006; Aubron et al. 2009; Meul et al. 2012), Sociology for questions about the social trends and norms that lead to workforce organization (Nye 2018), and Ergonomics to analyze working conditions (Jafry and O'Neill 2000). Livestock scientists and in particular French ones have worked on this subject since the 1980s, because their view has been that the changes in livestock management had to be taken into account through the influence of these changes on the work: New herd management practices and land uses modify the work, its rhythm and its duration of work, the possibility of changing the timing of tasks, the competence or know-how required, and workforce. As in other activities, adapting management (simplifying, prioritizing) to overcome work constraints can be observed on livestock farms. In the framework developed by French livestock researchers to analyze the work organization of livestock farms, the work is considered, like in Ergonomics, as the association between tasks and workers (Leplat 1994), and work organization as the management of the "tasks-workers" system. Work organization pays attention to the tasks (which stem from the production choices and practices), to the people on the farm and to their association, looking at the adjustments that make it possible to account for the changes in activity in relation to the evolution of work situations (Cellier and Marquié 1980). The framework considers work organization to be a system connected to the livestock farming system model of livestock scientists Gibon et al. (1999) (Fig. 1), the two systems being the two faces of the same "farming system" coin. The farmer is considered both as the technico-economic pilot and the work organizer. The work organization system connects the household activity system, the agricultural production tasks, the family and the external workforce, the buildings, and the equipment.

The Work Assessment Method (WAM) was the first application of this framework (Dedieu and Servière 1999). It was designed for the use of advisers and farmers, as a tool to help the global analysis of livestock farming systems from a work perspective. The Work Assessment Method quantifies the work related to the management of herds and land areas, and evaluates the farmer's room for manoeuvre in terms of the time needed to carry out activities on the farm, and to have free time.

The Work Assessment Method has been used for 25 years to produce standard work times, to analyze the determinants of work time and organization, and to develop training and advisory tools in France, some European countries, and some countries in the South via joint projects (networks or international projects) (Dedieu and Servière 2012).

The purpose of the paper is to present the WAM, to share some of the knowledge produced, and to discuss its benefit for tackling the issue of work organization on livestock farms. We chose to do a comparative analysis of studies conducted in six widely different countries (Belgium, Brazil, France, Morocco, Uruguay, and Vietnam) to develop generic ideas (i) on work organization indicators and their variation and (ii) on knowledge produced about work organization using WAM. The discussion is in three parts: (1) the specific features of the framework; (ii) the adaptability and limits of the method; and (iii) the contribution to advice, research, and training. 
Fig. 1 The two sides of the livestock farming system functioning: livestock and resource management, and work organization (Dedieu and Servière 2016)

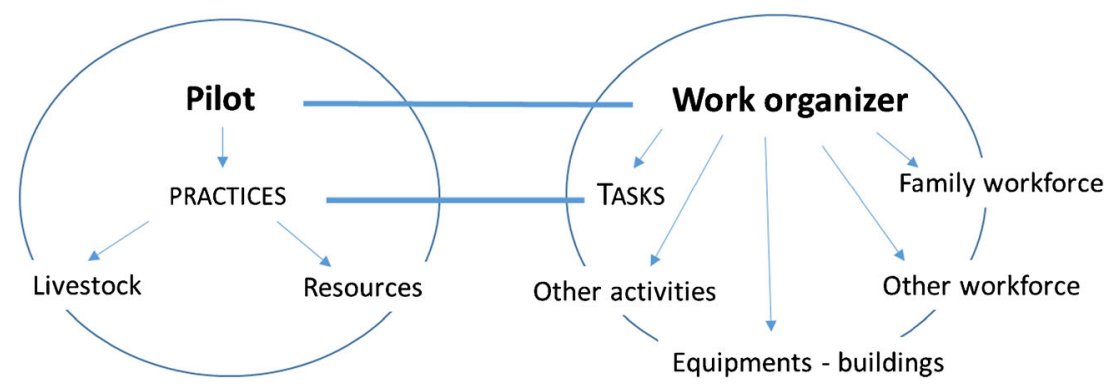

\section{The Work Assessment Method: a brief presentation}

\subsection{A framework of work organization based on three principles}

The Work Assessment Method (Dedieu et al. 2000) translates the technical calendar (herd and land management practices), into a calendar combining tasks and workers, taking into account (i) the particular temporal characteristics of tasks (daily or seasonal, that can be postponed or not), (ii) the diversity of workers, and (iii) the variety of temporal scales (Fig. 2).

This framework of work organization is based on three principles:

Different workers. All the workers are not equivalent according to their function within the work team, their involvement, and the way they are paid for their work. The WAM defines two workforce categories: (i) The Basic Group (BG) consists of workers for whom agricultural work predominates in time and income, such as farmers, farming couples, and farm business partners. They organize the farm work taking into account their own wishes about work (e.g., duration, other activities). (ii) The workforce outside the Basic Group is composed of employees, mutual assistance, subcontracting companies, and unpaid labor (e.g., retired people and people giving a hand).

Different tasks. The tasks are not equivalent because they have different rhythms and different possibilities of being postponed. The WAM defines two types of task: (i) Routine work (RW) has to be done almost every day and can be neither aggregated nor postponed. Routine work can be daily (care of the animals, milking), or not daily (participation at markets which take place on a fixed day of the week). (ii) Seasonal work (SW) includes tasks that are easier to postpone and/or aggregate. It is composed of tasks linked to agricultural activities (e.g., herd, crops, forage areas, land upkeep) and non-agricultural activities (e.g., commercialization, diversification, or services).

Different work organizations over time. The work organization in a calendar year results from the sequence of periods whose organizational characteristics are different (due to the cycle of the tasks to do, to the manpower, or to the combination of activities). These periods of time have the same daily activities. They are not defined a priori, but they have specific forms of interaction between the technical imperatives, the workers' work rhythms, the pressure of non-agricultural activities, and the work organization expectations.

\subsection{Methodological choices}

\subsubsection{Data collected by survey with analytical reconstitution of work duration}

Developed in a research/advice collaboration, the Work Assessment Method has to match not only the research interests, but also the objectives of agricultural advisors and their work rhythms: It must be applicable to diverse and large-scale farmer populations, without requiring long data collection phases, and it must include quantitative data. For this, the core of the survey consists of an "analytical reconstitution" of work over the farming year by a semi-directive interview lasting 2 to $3 \mathrm{~h}$. This approach of work duration from Lacroix and Mollard (1991) is preferred to the Time Budget method (Riegel and Schick 2007; Gleeson et al. 2008), or to the Timing Methods (Morgan-Davies et al. 2018), which are not adapted to be used by advisors performing a diagnosis at the scale of the farm and for a year. During the interview, periods with a constant duration in the daily routine work are defined in relation to herd management phases (e.g., over-wintering, turning out to grass, reproduction sessions, milking periods). For each period, the farmer specifies the hours worked daily by himself and the other workers and describe its contents. Finally, the different types of seasonal work are defined by theme (e.g., herd handling, fodder operations, crop operations, marketing), and quantified in days.

The method does not use an exhaustive categorization of all of the elementary tasks to capture the durations and does not take into account interstitial work (which takes place when time is available), such as equipment maintenance, or nonmanual work, such as management, training, or work 
Fig. 2 From a technical calendar to work organization combining tasks and workers (Madelrieux and Dedieu 2008)

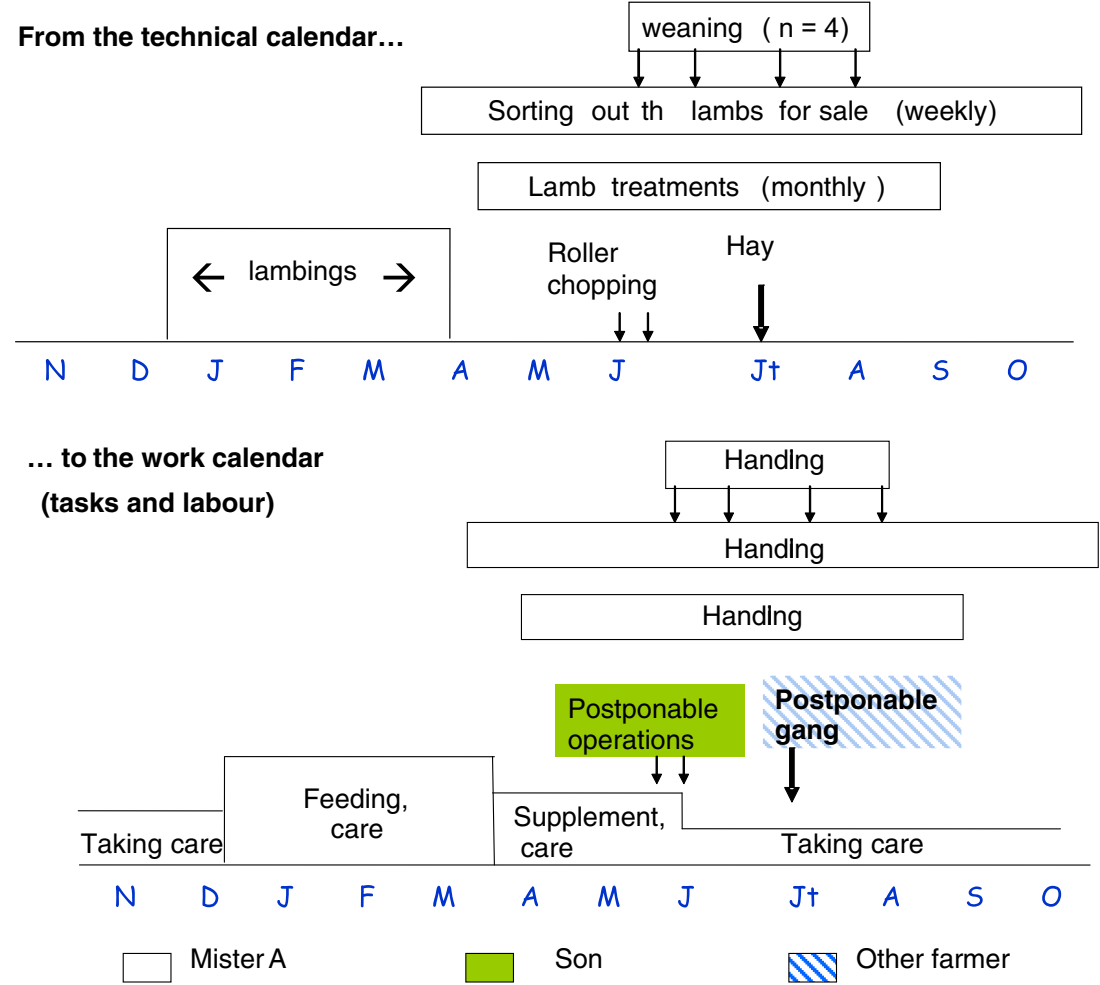

associated with decision-making. By choosing to take into account work characteristics over time, and characterizing the interaction between the types of tasks, the method does not consider elementary or functional tasks (milking, feeding: functional as far as animal production is concerned) to quantify the duration. But, the information on the content of the routine work or the seasonal work is mobilized for a qualitative interpretation. The quantification of some functional grouped tasks is possible when it is easy to identify a beginning and an end, but not necessary to capture the farm work organization.

\subsubsection{Criteria for assessing work organization}

The Work Assessment Method looks at workforce configuration, and it characterizes and quantifies the different work, defines work sequences during a year with a common form of daily work organization, inter-relates the different sequences, and identifies peaks. The data on work time are computed to produce indicators on workload by category of workers (BG and outside the BG), the type of work (RW and SW), and on the efficiency and flexibility of work organization. The work efficiency indicators are calculated by ratios (e.g., number of hours of routine work per livestock unit, or number of days of seasonal work per hectare of used agricultural area). The flexibility indicator, the calculated time available (CTA), which represents the time left for the Basic Group to perform other unrecorded tasks, or to have free time, is calculated as shown below. The computing of data enables the production of graphics about the distribution of work time and calculated time available over the year, by 2 -week period. The main concepts and indicators of the WAM are shown in Fig. 3.

\subsubsection{Calculation choices}

For the WAM, Routine work is measured in hours, and Seasonal work is measured in days.

The Basic Group (BG) is taken to be the number of workers belonging to it $(\mathrm{pBG})$, without making any assumption about the annual duration of agricultural work for each of them. The formula used to calculate the time available (in hours per year) of the Basic Group is as follows:

$C T A=\sum_{l}(\mathrm{Jdi} \times \mathrm{Hdi})$

where $i$ represents a period where routine work has a constant duration; Jdi the number of days available during period $i$ for performing non-quantified tasks; $\mathrm{Jdi}=[$ (number of days in period $i$-number of Sundays) $\times$ (number of workers in the Basic Group)] - [number of days spent by the Basic Group on seasonal work during period $i$; Hdi the number of hours available per $8 \mathrm{~h} /$ day once all routine work has been completed (during period $i)$; and Hdi $=[8-($ number of hours of routine work carried out by the Basic Group / number of workers in the Basic Group)]. The CTA calculation is as follows: 
Fig. 3 The main concepts and indicators of the Work Assessment Method

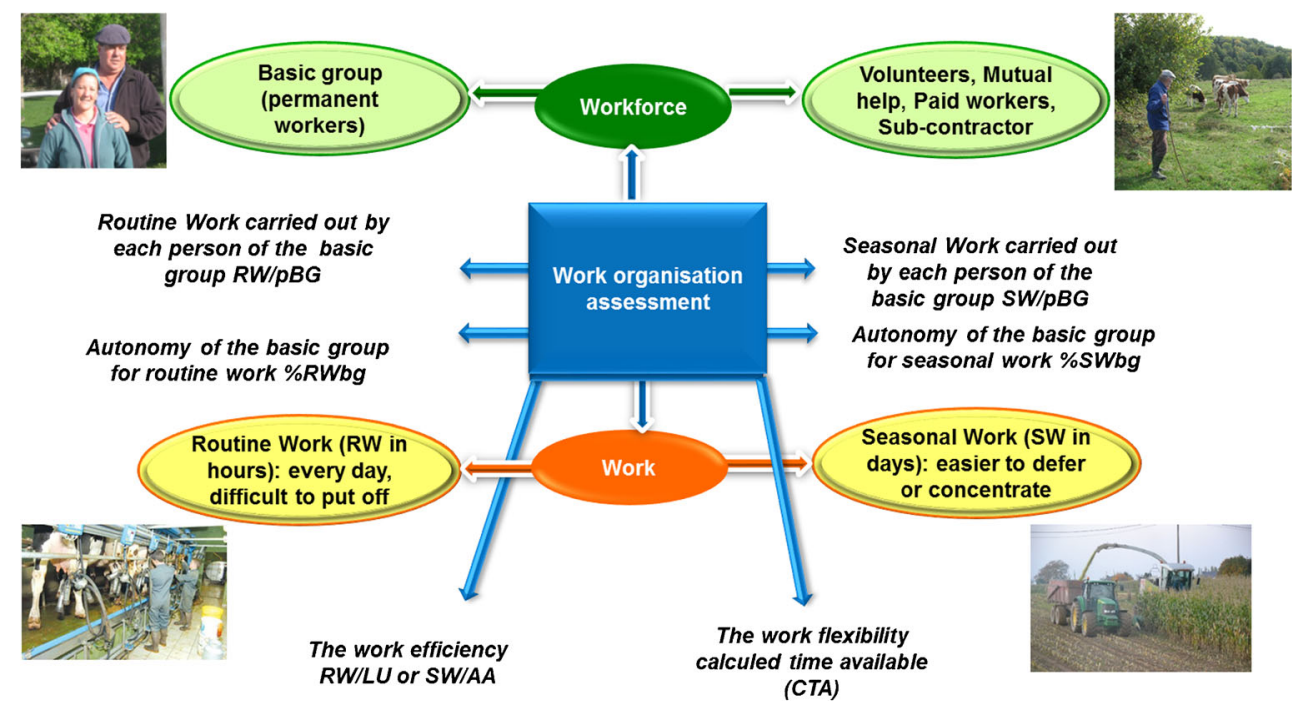

- Sundays are part of private time, except for the routine work: no room for maneuver on Sundays.

- The days occupied by seasonal work (SW) are full days: no room for maneuver on SW days.

- For the other days, the available hours are calculated with a reference duration for a workday of $8 \mathrm{~h}$ per person of the Basic Group.

All the calculations of work time are done for each calendar 2-week period.

\section{Comparative analysis of case studies}

The analysis was built on the comparison of case studies from different countries which cover a wide range of contexts, livestock farm types, and work problems.

\subsection{Explanation of the approach}

For inclusion in this comparative analysis, a research paper was chosen only if it tackled work organization on livestock farms using the Work Assessment Method.

The nine case studies selected are in six countries: two from the north, France and Belgium; four from the south, Vietnam, Morocco, Uruguay, and Brazil (Table 1). For France, where the Work Assessment Method has been used for more than 25 years, and where there has been many studies and papers, it was necessary to select a number of specific case studies. In other countries, studies are not so numerous and were based on smaller samples than in France. They mostly concern dairy farms, and some suckler farms in
Uruguay. The international studies result primarily from partnerships as part of international projects, or via the Mixed Technological Network (MTN) "work in livestock farming" (Kling-Eveillard et al. 2010).

We developed an analytical grid to extract data from the case studies as follows: the type of livestock farming system concerned, the aim of the study, the role of work organization in the issue addressed, the changes made to the Work Assessment Method, the WAM indicators used, and the main results for work organization.

The analysis of the case studies was carried out using two different types of comparative analysis (Lallement and Spurk 2003). First, we examined the raw data produced by all the studies to present and illustrate the work organization indicators, then the variation in the indicators and the way they provide information about the general characteristics of work organization on livestock farms and on the specific details related to the context of the case studies (Paragraph 3.2). Second, we modeled generic patterns of work organization (Paragraph 3.3). For that, we applied the method used by Cournut et al. (2010) to give less weight to local characteristics (e.g., not much mechanization in the south; very different farm size in Vietnam compared to Uruguay): The variables used to compare the work situations were expressed relative to the intra-study variation. The generic patterns of work organization were modeled using the ideal-type approach of Weber (2003).

\subsection{Knowledge produced about work organization}

From the case studies, the different types of knowledge produced by the WAM are presented and illustrated. This is done 
for the configuration of the workforce, the different tasks, the implementation of work over time, and the efficiency and flexibility of the work organization.

\subsubsection{Workforce configuration}

The WAM analysis describes the configuration of the workforce, starting with the composition of the Basic Group. In our case studies, the family-based Basic Group is mainly composed of one or two people, but the number of people varies from none in a Uruguayan farm (because the farmer has delegated the management of his farm to a "capataz" (foreman) managing a team of workers), to 5 people in some French dairy farms. The number of people in the BG is influenced by the production sector (often one person in meat sectors, but at least two people in general for dairy farms where milking is part of the workload). The combination of farm activities also affects the number of people in the BG: Introducing new activities is often a way to create a job for new family members (Sraïri and Ghabiyel 2017; Rault 2005; Mundler and Jean-Gagnon 2017). Farm size also influences the BG. For farm size, the general rule is that the number of people in the BG increases with the number of animals, but it is not always the case because other factors influence the maximum number of animals that a breeder can handle, depending on livestock management, mechanization, and workforce outside the BG). Thus, in our case studies, we observe a wide range of values for the ratio of animals per person: from 3 dairy cows per person in Vietnam, to 249 in Uruguay.

The workforce configuration also takes into account the intervention of other categories of workers, outside the Basic Group, who give numerical flexibility to the work organization (Errington and Gasson 1996). The use of external labor is very variable across countries, production orientations, and farmer strategies. This leads to very different situations in terms of the autonomy of the BG in our case studies (from $0 \%$ in Uruguay to $100 \%$ (where the Basic Group performs all the work)). Paid labor is common in Uruguay and in the larger dairy farms in Vietnam, even with very different farm sizes (7 ha in Vietnam vs 1700 ha in Uruguay), and carries out all kinds of tasks (Cournut et al. 2010). In Brazilian and Moroccan case studies, paid labor is used mainly for seasonal work on grasslands and crops. In France and Belgium, paid labor is not very common in dairy cattle farms, but more common in pig farms and farms producing goat's cheese. Unpaid labor is widely used on the family farms studied; it is a workforce reserve that provides flexibility (Mundler and Laurent 2003) for different scenarios: at peak times (calving, harvest, etc.), when the tasks require labor (e.g., collecting the animals together), when there is competition for labor between activities, and when the economic situation does not allow payment of labor. Sometimes, the operation of the system can depend on when certain unpaid workers are available (e.g., schoolchildren in Brazil, Uruguay, and Vietnam). The 
continuity of the system can also be questioned when a large part of the daily work (milking, guarding) is carried out by someone who is retired. Mutual assistance is another kind of unpaid labor, found mainly in Vietnam and in France for harvesting fodder, but it is in decline because of the reduced number of farms, increased mechanization, and the increasing use of contractors (Kunda et al. 2002; Anzalone and Purseigle 2014).

\subsubsection{The different tasks}

By differentiating between routine and seasonal work and quantifying them, the WAM helps the understanding of what is structuring the work of the farmer, by day, by season, or by year.

For example, in the dairy farm case studies, milking is the most structured and time-dominant feature of the routine work (approximately $50 \%$ of RW), except in the case of Moroccan farms where it was fourth in importance (16\% of RW), after feeding, grazing, and mowing grass (which often require long journeys). But, the milking time does not always include the same basic tasks depending on the system and country. In the majority of European situations, it corresponds to herding the animals together, distributing the concentrates, milking, and cleaning the equipment, whereas on dairy farms of the Brazilian case-study, the preliminary suckling by the calves to start the flow of milk, and milk transport to the refrigerated tank has to be added. The amount of milking work in the routine work of dairy farmers also depends on the equipment available (milking machine vs hand milking) and is changing with the development of automatic milking systems in France and Belgium (Jago et al. 2013; Hostiou et al. 2017). The routine work on beef cattle farms is more structured by the feeding and the care of animals. In Uruguayan mixed cattle and sheep farms, the routine work consists of the "recorrida" (the round-up carried out on horseback twice a day, to monitor and care for the animals, give supplementary feed, and manage the grazing) and is at the heart of what it means to be a "gaucho" breeder.

In most of the studies, the work devoted to the forage area is the main seasonal work, except in poultry farming where the main seasonal work is primarily associated with the removal of animals and the cleaning of buildings. In the southern countries, like Brazil or Vietnam, seasonal work forms a greater part of the work (compared to northern countries), because much of it is carried out manually.

\subsubsection{Structure of the work time and time available over time}

The analysis of the distribution of work time over the year makes it is possible to understand how the different elements of the work organization framework interact in the structure of work time. Indeed, for each country/system, the work consists of a specific composition of tasks associated with a type of livestock production, characterized by the technical task management (e.g., daily green fodder), the equipment used to carry out the tasks (e.g., transfer of milk churns to a refrigerated tank; manual or robot milking), and the workforce availability. This combination generates different work times and different patterns of change in the routine work over the year. For example, Fig. 4 highlights the links between the types of livestock management (grouped calving or calving spread over the year, the influence of indoor or outdoor breeding), the workforce availability, and the distribution of the routine work.

The same links can be identified for the distribution of the seasonal work, but it is the putting together of the two types of work distribution (RW and SW), which can lead to the identification of the peak work periods, and the conflicts between the two types of work. The analysis of the CTA distribution over the year is a useful way to complete the assessment of the flexibility carried out with the annual CTA indicator (see below).

\subsubsection{Assessment of work organization: efficiency and flexibility}

The first dimension of work organization assessed by the Work Assessment Method concerns the work efficiency. The calculation of work time per productive unit (cows, $\mathrm{LU}, \mathrm{m}^{2}$ of poultry house, ha of crops) or produced unit (liters of milk) enables a comparison between farms within the same size and production type category. The variation of work efficiency intra category is often very big, and positioning his farm along this scale allows a farmer to estimate his margin for progress. Most of the case studies highlighted an economy of scale effect on routine work (improvement of efficiency with increasing herd size). This was not so obvious for seasonal work, and non-existent when this work was conducted manually and done with mutual assistance like in Brazil or Vietnam. But, the scale effect interacts with management (type of production, distribution of calving, feeding method, and forage system), buildings and equipment, the workforce, and the way it is mobilized. Figure 5 shows, for example, the work efficiency variation between French mountain and French lowland dairy systems and the "milking robot" effect (Fagon and Sabatte 2010). The work times and therefore the efficiency indicators must be analyzed, in taking care to compare "apples with apples." For the French and Belgium studies, where enough farms have been surveyed, the efficiency is compared for the same category of systems, that is, the same type of livestock management (mountain/lowland, specialized/diversified, etc.) and the same herd size.

Flexibility of work organization is the second dimension assessed by the WAM. It is measured by the CTA per person of the Basic Group. In all the case studies, the values of this indicator differ between the Basic Groups composed of one person and the Basic Groups with more than one person, as shown in Fig. 6 for the Belgian dairy farms. Analyzing the variation in this indicator gives information on other factors 


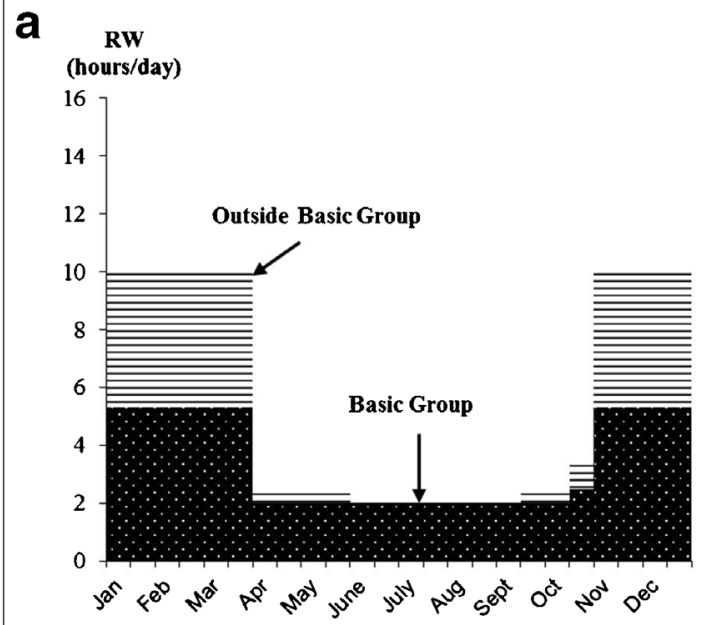

Fig. 4 Two profiles of the routine work on suckler cattle farms associated with the distribution of calving during the year, and the associated workforce (Cournut et al. 2009). a) U-shaped profile characterized by a marked break in the daily duration of the routine work (RW). Calvings are grouped in early autumn, and the daily routine work during the indoor period (November-March) is much higher than during the outdoor one.

which play a role in the CTA, such as the herd size, the recourse to labor outside the BG, the equipment, and the relationship between the farmer and his work.

\subsection{Generic patterns of work organization}

By analyzing the factors which impact on work times, the mobilization of the workforce, and the efficiency and flexibility of the work organization, most studies seek to understand and characterize patterns of work organization. Technical management, equipment, and number of animals per hectare affect the work efficiency and the total amount of routine and seasonal work done period by period. The configuration of the workforce affects what will be done by the Basic Group, and this has a strong influence on the CTA. This analysis of work organization permitted by the Work Assessment Method, and based on its framework (Fig. 1), considers the work organization as the contextualized expression of a particular combination of choices related to (i) dimensioning and combination of activities, (ii) technical management, (iii) equipment and buildings, (iv) configuration of the workforce (family and external) (Madelrieux and Dedieu 2008).

This framework has enabled us to identify from the case studies four patterns of work organization (Table 2) using the Weber ideal-type approach. These correspond to the recurring combinations of work components associated with particular efficiencies and flexibilities of work, and are described by variables expressing the intra-study variation by simple qualitative variables $(+,=,-)$. Technical management was not used

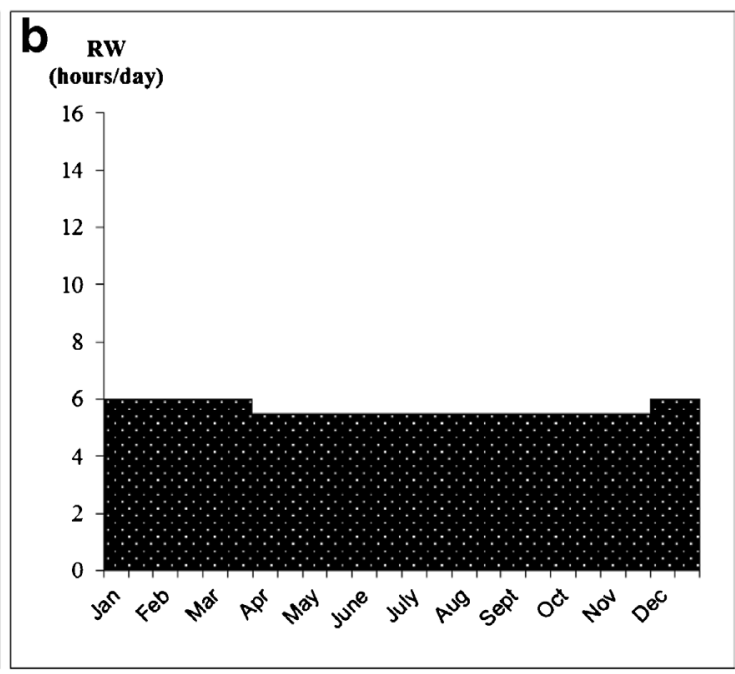

The routine work is carried out in winter by the farmer helped by his unpaid father, and only by the farmer during the pasture season. b) Flat profile with no notable modification to the routine work over the year. Calvings are spread over the year, wintering is without any evident impact on work, and the routine work is carried out by the farmer on his own

in the identification of these patterns of organization, because it was not taken into account in all the case studies.

"Delegation" pattern The "delegation" work organization pattern is characterized by large herd size, mechanization, and use of paid labor. This always shows a high work efficiency, but not systematically, with much room for maneuver in terms of time (CTA). This pattern was mainly found in Brazil, Uruguay, and Vietnam, where it was accompanied by a disengagement of the Basic Group from farm work. This may be absenteeism from the farm and so complete delegation, like in Uruguay. Generally, the livestock farmer retains certain strategic tasks for himself (marketing, monitoring the animals, milking). Delegation can also be found when farmers are more or less involved in other activities. In France, this pattern corresponds to farmers who work alone and have large herds (often suckler cows). They use external unpaid help and paid labor, and have high efficiency due to mechanization and/or the simplification of practices.

"Difficult" pattern The "difficult" work organization pattern is found for small farms with small herds, with no capital, no equipment, and with few resources, sometimes with no land (Morocco). These farms rely on heavy investment from the family in the work, even if off-farm activities exist. This configuration was mainly found in Morocco, Brazil, Uruguay, and Vietnam. In France, this configuration characterizes small farms managed by livestock farmers working alone, who have considerable use of unpaid help from the family for production that relies on a lot of routine work (dairy sheep, goat's cheese). This configuration has low efficiency and low CTA. 
Fig. 5 Routine work efficiency for French dairy farms vs the number of dairy cows and type of farms (Fagon and Sabatte 2010).

The shape of the dot indicates the type of system: farms with robot for the square, mountain farms for the diamond, and lowland farms for the triangle. The routine work is broadly less efficient in mountain farms than in lowland ones and than those who have a milking robot

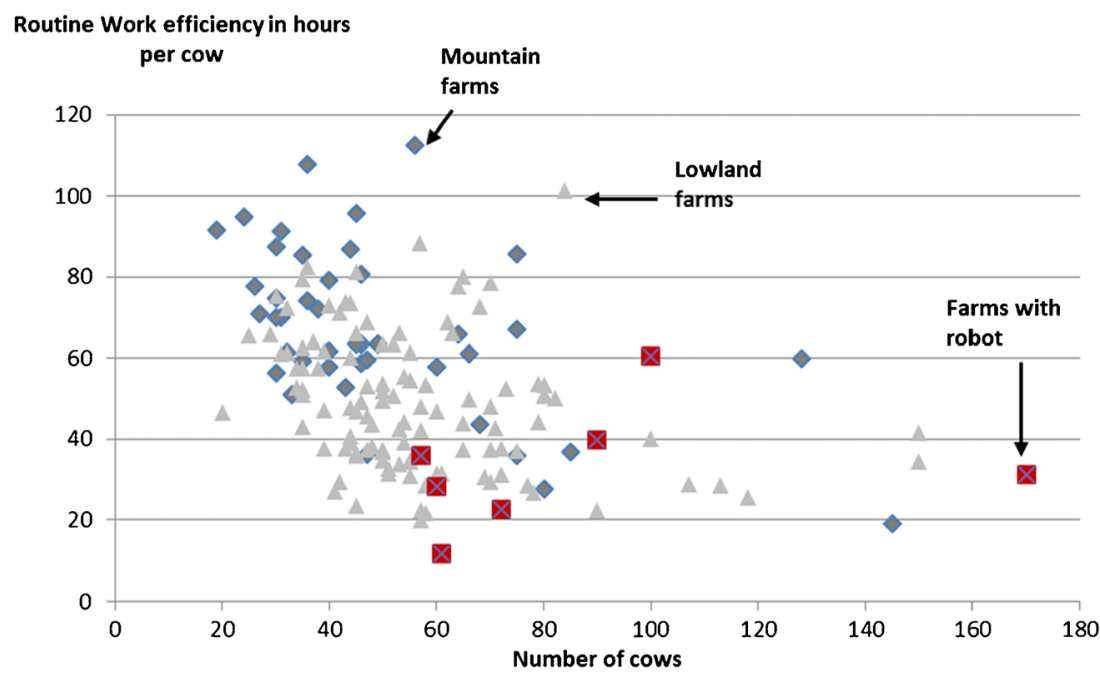

The two other patterns are more often found in Basic Groups composed of at least two people.

"Share" pattern This "share" work organization pattern is found for average-to-large farms managed by large family groups with several units, who are in a logic of "giving work to everybody" and "working together." In this pattern, the autonomy of the Basic Group is important both for routine work and for seasonal work; the efficiency and the CTA are average. Common in France in family structures that are often multi-generational, this pattern is also found in Uruguay and Brazil on family farms which use some paid labor (which is traditional in these countries).

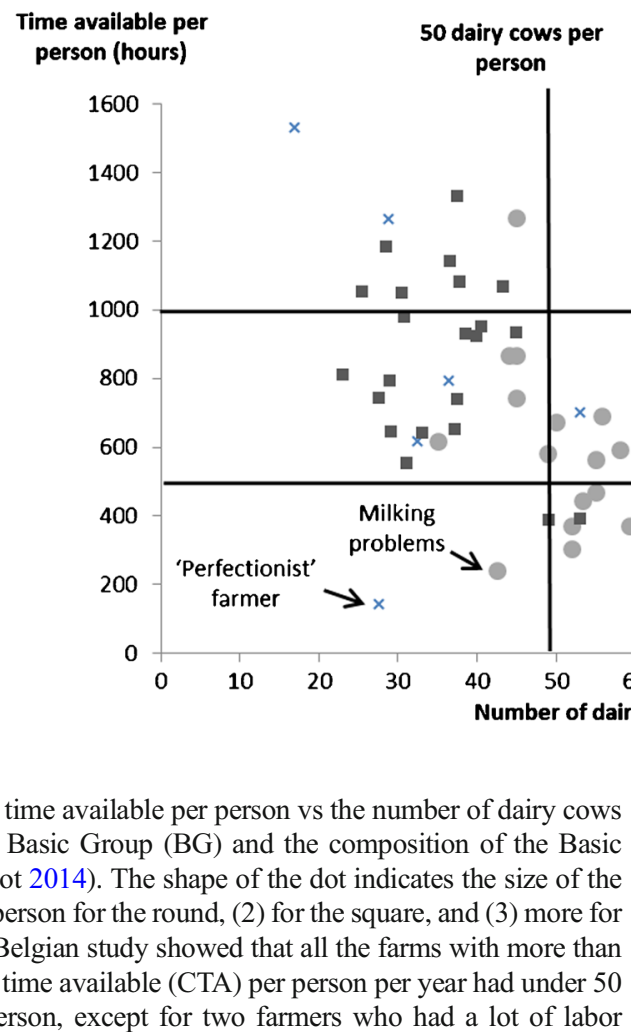

Fig. 6 Calculated time available per person vs the number of dairy cows per person of the Basic Group (BG) and the composition of the Basic Group (BG) (Turlot 2014). The shape of the dot indicates the size of the Basic Group: (1) person for the round, (2) for the square, and (3) more for the crosses. This Belgian study showed that all the farms with more than $1000 \mathrm{~h}$ calculated time available (CTA) per person per year had under 50 dairy cows per person, except for two farmers who had a lot of labor
"Adjust" pattern The "adjust” work organization pattern is found on small-to-medium sized farms where the system is governed above all by matching the work to the available Basic Group composition. This pattern is mainly observed on farms with a Basic Group composed of a couple. The temporary needs for certain work peaks (e.g., harvest of crops) are satisfied by delegation to a workforce outside the Basic Group. This pattern has been identified in France for specialized dairy cattle systems, but also in Uruguay, Brazil, and Morocco for farms which are sometimes diversified.

These patterns of work organization do not break down in the same way as the analysis by Cournut et al. (2010), because available outside the BG. Conversely, those farmers with under $500 \mathrm{~h}$ CTA per person per year generally had more than 50 dairy cows per person. The exceptions in the bottom left of the figure were analyzed by the authors and explained by (i) milking problems and, (ii) for one farm, by the special relationship between the farmer and his work: He is a "perfectionist" and does not count the time he takes to do his work 
Table 2 The four patterns of work organization

\begin{tabular}{lllll}
\hline & Delegation & Share & Adjust & Difficult \\
\hline Configuration of the workforce & Farmer + employee & Family group & Farmer couple + intermittent help & Farmer or family with unpaid help \\
Dimensioning & + & + & $=$ & - \\
Combination of activities & $=$ & + & $=$ & + \\
Equipment/buildings & + & $=$ & $=$ & - \\
Basic Group autonomy & - & + & + & - \\
Efficiency of work & + & $=$ & $=$ & - \\
Flexibility of work & $=$ & $=$ & + & - \\
\hline
\end{tabular}

The variable describing these patterns are expressed relative to the intra-case study variability. "+" corresponds to high value, "=" to average value, and "-_" to low value

the data available are not the same, especially in relation to technical management. In some countries, where dairy farming is quite recent, like Vietnam, the technical management of dairy herds is homogenous and depends on the downstream industry, or on a homogenous technical organization which has a strong effect on the structure and development of the activity (Cournut et al. 2010; Dieguez et al. 2010; Hostiou et al. 2015). In other countries where traditional, modern-intensive, and ecological agriculture patterns co-exist (Lémery 2003), the influence of the technical choices on work organization merits attention. As noted in Cournut (ibid), the patterns do not seem to be related to local circumstances, because they are found both in northern and southern countries. The work organization patterns are strongly influenced by the configuration of the workforce which seems to control the organization of work as underlined by Solano et al. (2006). This means that the configuration of the workforce should be taken into account, rather than just counting human work units.

\section{Discussion}

In this section, we discuss the relevance of WAM for tackling work issues, giving first details of its specific features, then questioning its adaptability and limits, and finally providing an overview of its main contributions.

\subsection{Specific features of the framework}

The WAM was developed as a transdisciplinary approach, borrowing from the ergonomics, economics, rural sociology, and farming systems disciplines.

Two major ideas were taken from ergonomics: first the definition of work centered on the coupling of people and task, the work activity (Leplat 1994). The operator is not only an executive man (or women), but he also adapts his way of working and he learns by working (Coquil et al. 2014). The farmer, being the farm manager, and a major operator is very concerned by adaptation either at the task level or at the farming system level. Second, work organization on livestock farms is not the organization of additive tasks (feeding the animals, milking, plowing, harvesting), each with its given duration, but the combining of tasks that have very different rhythms (Cellier and Marquié 1980), some daily, others seasonal. Livestock farming is marked by the importance of daily rhythms, the daily care of animals which must be done every day, no matter what was done the day before, and the conflicts with other tasks (peak of seasonal tasks).

The methodological option of using work duration estimation on a calendar year, with attention to the periods depending on management choices (wintering dates, reproduction sessions...) was taken from Lacroix and Mollard (1991), searchers in economics. These authors deeply criticized the ability of "equivalent full time worker" indicator to deliver knowledge on the working durations associated with the annual operation of a farm. A "full time worker," present and active at $100 \%$ the whole year in a farm, can work $1800 \mathrm{~h}$ per year (typical for paid full time workers in France) or $4200 \mathrm{~h}$ per year (highest duration estimated by Jean et al. 1988). Timing, adapted to the analysis of elementary tasks or welldefined technical operations (Morgan-Davies et al. 2018), is not applicable at the scale of a farm where the variety of work and their inter-linking are too important. Time Budget methods (O'Brien et al. 2006; Gleeson et al. 2008; O'Donovan et al. 2008; Bostad et al. 2011) are very selective methods, with doubts about the veracity of what farmers record, and the Timing Methods appear to be imprecise for a full year declaration. These methods use a work diary written by the farmer for samples of days by season, with a classification of tasks independent of their rhythm. The WAM adopted the analytical reconstitution of work duration approach from Lacroix and Mollard (1991), based on a step-by-step reconstitution of the task duration, considering the major events that mark the seasons (wintering of the animals, calving, harvesting periods), and the daily breaks the farmers have (breakfast, lunch, etc.). The precision of WAM was compared to the Time Budget method and had a routine task error of half an hour per day and a seasonal task error of half a day per month (Dedieu 
et al. 2000). The absence of seasonal or daily breaks for more interstitial tasks (that take place when time is available), but are not directly connected to the herd and land management, explains the decision to not estimate this third type of work and therefore to not estimate the total annual working time.

The necessity to consider all the categories of workers, and to differentiate them according to their status, function in the work team, their rhythm of involvement, and the manner in which they are remunerated for their work was taken from rural sociology.

From the farming systems approach, the WAM framework took the connection of the livestock farming system model (Gibon et al. 1999) to the work organization system (Fig. 1), assessing the efficiency and flexibility of the work organization by WAM indicators, but also considering the other elements of the system to approach the levers of work organization: hiring workers, investing in larger equipment, and prioritizing farm to other activities (Madelrieux and Dedieu 2008; Hostiou and Dedieu 2012).

The WAM offers a framework which is able to describe in a very practical manner the work organization at farm level, taking into account the specifics of livestock farming activities. Its main strengths come from its framework principles and methodological choices. But, it has some limits.

\subsection{Adaptability and limits of the method}

The WAM has been used in different farming contexts, and to pursue different objectives. In the case studies selected, the objectives were to identify the influence of production sectors, combination of productions, or farm size on work organization, to analyze work remuneration, to produce standards for working time, and explore the value of work organization analysis in understanding farmers' strategies. In this section, we present the questionable points of the method, which were highlighted in the case studies by the adaptations to WAM made by the authors, and include these research experiences in a broader literature dealing with work analysis in livestock farms.

\subsubsection{What about other work dimensions?}

Work is multifaceted (Kling-Eveillard et al. 2012). It can be regarded as an organization structuring a variety of farming or private activities over a period of time, a resource to be optimized with economic competitiveness in mind, or a profession which builds the personal and professional identity of the livestock farmer (Dedieu and Servière 2012). The WAM deals with the first dimension. The Moroccan case study is the only one to tackle the economic dimension calculated with the WAM data, comparing the work (routine + seasonal) remuneration of different livestock farms. To do that, the authors had to estimate the total work time in hours: They chose to measure SW in hours (assuming that a seasonal day of work is equivalent to $8 \mathrm{~h}$ ) and add the value obtained to the RW.
These changes to the method, found also in the recent study by Mundler and Jean-Gagnon (2017), who looked at the productivity of farms using local marketing practices, are at the limit of the methodological framework of the method. Indeed, the units for quantifying seasonal and routine work (days and hours) were chosen to take into account the different level of precision of this estimate by the analytical reconstitution of work duration. The accuracy of the value obtained by summing the two types of work is thus questionable. Secondly, the productivity of work must be evaluated by taking into account all the tasks carried out by all the workers involved in production. However, the method does not allow to take into account all the tasks, especially the ones that are interstitial. The creators of the method accept that it is not suitable to analyze total work productivity, which can be done with more global estimations of the quantity of work, through Agricultural Work Unit (Charroin et al. 2012; Veysset et al. 2015; Veysset et al. 2017), or more precisely with the Time Budget approach (O'Brien et al. 2006). In any case, evaluating the productivity of work assumes taking into account the work done by the different categories of labor, including those who do not expect remuneration, which complicates the interpretation of the results and any reporting to farmers. The method is not the best to grasp the economic dimension of work, but it gives some indications to understand the work productivity strategy. The enhancement of routine work and seasonal work efficiency is one of the levers of the work productivity improvement (by equipping, increasing the size of the herd or area, specializing, etc.) but not the only ones: The global productivity may for example be improved by the diversification of the farm activities, because it densifies the work calendar (Cochet 2015).

WAM does not clarify the view livestock farmers have of their own work, even if in each case study, these views are present in the farmer's justification of the organizational choices. Dufour and Dedieu (2010) showed that the connection of farmers to their work is diverse, finding in dairy cow farming (Massif Central, France) three types: The first type wants an organized work, as a sign of modernity (taking into account the issue of work productivity and/or the need to have free time like other professions), the second type considers working with the animals as a passion and does not count their time, and for the third type, the work is overwhelming, difficult, and endured. Recently, work has been undertaken to complete the analysis of organization by the WAM by looking at the meaning of job and the productivity of the work (Fiorelli et al. 2012; Chauvat et al. 2016).

\subsubsection{Taking into account tasks}

The WAM was originally designed to quantify the work related to the management of herds and land areas, but has evolved to 
take into account other activities directly linked to the production process, such as the processing and commercialization of animal products. This type of work, which cannot be postponed but has a non-daily rhythm, was designated as non-daily routine work (Dedieu et al. 1999), and included in the calculation of the RW after recording at the week scale, and smoothing of the hours counted over 7 days. So, the irregular weekly rhythm of the RW, which characterizes also the work in pig farms, is not precisely taken into account by the WAM, whereas it can strongly affect the sequencing and organization of work (Martel et al. 2008).

Another type of routine work was included in the analysis in the Uruguayan case study. It is the management work that is essential in this type of livestock system where the paid labor force is normal and where a significant part of the work of the farmer is to manage the different types of employees. This type of work was also taken into account in the study of Mundler and JeanGagnon (2017), to account for structuring activities such as management of the workforce and invoicing. With the increase of wage earners on livestock farms (Hemme and Otte 2010; Shreck et al. 2006), this management work is probably to be taken into account in the future.

Some of the case studies have sought to quantify RW by main task category (milking, feeding, etc.), thereby coming closer to the more analytical studies of work time, in which work is timed (Ferris et al. 2006; Morgan-Davies et al. 2018). This refinement of the analysis is possible for certain categories of tasks for which it is easy to identify a beginning and an end. It allows a focus on some key livestock activities, such as milking (Fagon and Sabatte 2010), but must be used with caution when comparing different situations, because the task category can include a wide and variable range of elementary tasks (see above).

\subsubsection{Taking into account workers}

The categorization of workers proposed by the WAM is also questionable.

Three of the southern country case studies (Brazil, Uruguay, and Morocco) attempted to be more specific, quantifying the place of women in the work carried out by the Basic Group. The gender of the worker is not taken into account in the categorization of workers for the WAM, particularly those in the Basic Group; investigation of the specific contribution of women would require an adaptation of the method. However, women play an important role in the management and development of farms (Contzen and Forney 2017).

The categorization of employees, not accounted for in the WAM, takes part of the characterization of work organization in some studies, like in Uruguay where the capataz (foreman), the peon, and the occasional workers are identified separately. The work delegated to employees is sometimes analyzed to understand the delegation strategy, with some farmers delegating different amounts of the obligatory work, either to free up time for a job in town, or to avoid having to deal with the most arduous tasks (Nicholson et al. 2004). The strategies of work delegation and the development of employee workers put into question the meaning of job of the livestock farmer and have financial implications which are not neutral (Errington and Gasson 1996; Malanski et al. 2016).

The increase of wage earners on livestock farms questions the nature of the tasks and the categories of workers to be taken into account in the WAM, but also the way of carrying out the survey itself: Data were collected by interviewing one person per farm: the farmer. The method needs to be adapted to better take into account the evolution of the work teams, and to better analyze the role of specific categories of workers.

\subsubsection{Flexibility assessment}

Much discussion surrounds the issue of how the CTA should be calculated. The choice of a standard workday of $8 \mathrm{~h}$ for the calculation of time available may seem too far from the reality of livestock farmers in some countries. These rules, even if they sometimes result in a rejection of the method, make it possible to obtain the same basis for comparison (Aubron et al. 2016) and show a large variation in flexibility (from 0 to $1800 \mathrm{~h}$ of CTA per person per year). Furthermore, the figures produced do not have much meaning in themselves for farmers because they are not "tangible." They acquire their full meaning within a comparative framework insofar as they enable the different methods of constructing the CTA (corresponding to the different ways of organizing the work at year level) to be analyzed (Cournut et al. 2009).

Another subject of discussion concerns the relevance of the CTA indicator for assessing the flexibility of work organization. The sources of flexibility (Darnhofer et al. 2010; Dedieu and Ingrand 2010; Nozières et al. 2011) allowed by the work organization merit a better evaluation than this annual indicator of the saturation of working time relative to potential annual availability. The WAM produces data on distribution of work time (RW and SW by fortnight) and available time (CTA by fortnight) over the year, which could be used to build indicators taking into account peaks of work, and periods when there is little room for maneuver. Flexibility as measured by the CTA is more an estimation of the buffer capacity linked to the organization of work, than the capacity of the work organizer to develop an adaptable management of the daily work (who does what) due to the effects of weather conditions or worker availability (Dedieu and Ingrand 2010; Milestad et al. 2012). It is from this aspect, to take into account not only buffer capacity but also adaptable management, and the regulation of daily work organization (Madelrieux and Dedieu 2008), that the QuaeWork method was developed (Hostiou and Dedieu 2012). QuaeWork uses the Work Assessment Method for the characterization of work 
times but takes into account the coordination between the different tasks, whether they are routine, seasonal, or related to offfarm activities. In addition to the quantification of work times, the method also makes it possible to describe the work organization flexibility using additional indicators, taking account of the sequence of periods and standard days at the scale of the farming year (adjustments of periods, rhythms of standard days, and origin of the periods). Other elements can also be considered to account for the flexibility of the work organization, such as the possible use of outside labor (numerical flexibility cited by Mundler and Laurent 2003 and Nye 2018), the versatility and replaceability of the workers (functional flexibility), and the porosity of the organization (Jean et al. 1988), that is its ability for the famer to alternate periods of work with periods of non-work (the method does not quantify these non-work times by week, year, holidays, or weekends). These different aspects should be questioned in addition to the WAM diagnosis to complete the flexibility assessment (Chauvat et al. 2016).

Finally, the question of evaluation refers to the norm to which the calculated values must be compared. The flexibility of a work organization is assessed by comparing the CTA obtained on a farm with data coming from similar configurations or reference work time. Like other work times, the variability of CTA is always very high, and this comparison only gives a few elements to look at the margin for progress. However, the numerous studies carried out in France have made it possible to determine empirically thresholds of "livability" for the CTA (Cournut and Chauvat 2012). It has been considered that a CTA of less than $500 \mathrm{~h}$ per person of the Basic Group corresponds to difficult situations, from 900 or $1000 \mathrm{~h}$ is regarded as more comfortable. In most studies, a large percentage of farms have a CTA below 900 h. This merits discussion with livestock farmers, because a low CTA value does not necessarily mean a bad work experience nor bad working conditions. On the other hand, these threshold values must be adapted to the specifics of each country to take into account the technical characteristics of the work and also social and cultural values.

\subsection{Contribution to advice, research, and training}

Thanks to the development of a research/advice/training community on the theme of work in livestock farming, the usage modalities and contributions of the WAM are numerous.

Firstly, they concern advice. WAM completes a systemic analysis approach to the functioning of livestock farms. It has been specifically developed to be compatible with technicians and engineers' workloads and work habits, by being a halfday survey. This method has been used to produce reference work times: In France, the seven main animal sectors (dairy and suckler cattle, dairy and meat sheep, dairy goat, pig, and poultry) now have reference work times. These contribute to the development of viable, livable, and reproducible farm models, combining the characterization of practices and techniques, the economic results, the volume of work required, and the work distribution according to the technical calendar and types of workers (Jousseins et al. 2011).

The WAM is useful for individual advice on the subject of work. Data presented, and in particular the comparisons between farms (differences in working hours, contribution of different categories of workers, etc.), make it possible to start thinking about work organization and the overall functioning of the system. It sheds new lights on the farmer's perception of his work, and on his ability to analyze and change his system. Other disciplines have been used to analyze and complete WAM data, with more sociological and psychological approaches (meaning of the job, work representation, suffering at work Fiorelli et al. 2012; Kling-Eveillard et al. 2012; Porcher 2017), or ergonomic approaches (Sarzeaud and Chauvat 2011).

The WAM may also be used to contribute to group discussions. From an individual expression of "work problems," the groups may evolve to a collective discussion structured around analysis of the work data and its organization. Often, these meetings are followed by visits to farms "in turn," during which the farmers express their opinions, even their criticisms, of their colleague's real working practices and consider solutions together. The thought process can also begin by several of them recruiting an employee or with an opportunity to modify management practices. The adviser is less a prescriber of solutions than a guide to thinking about a subject on which the personal points of view (on work with the others, family agreements, etc.) are expressed, going further than the quantification of work periods and the descriptors of the organization (Dockès et al. 2018).

The WAM can be also used for training. In France, the method has long been included in training courses for different audiences (apprentices, technicians, engineers, advisors, and teachers). A teaching guide has been published with the participation of the Ministry of Agriculture (Bischoff et al. 2008). In Belgium, a network of work advisors was created in 2015, and a training session was organized (Dockès et al. 2018). In Uruguay, a distance learning (MOOC) on the WAM was set up, for advisors and teachers (Dieguez 2009).

The method is used by researchers, as shown in this review, to answer questions about work on livestock farms, but also more broadly in studies that want to take into account the work dimension to evaluate systems, or study their transformation (Ryschawy et al. 2014).

\section{Conclusion}

The Work Assessment Method, developed by French livestock researchers, provides a framework capable of capturing 
work organization, taking into account the specifics of the livestock activity. This analysis gives generic ideas on work organization indicators and their variation, and on knowledge produced about work organization. Four patterns of work organization have been identified, which are not linked to the local context but marked by the workforce composition.

We show that the relevance of the WAM to tackle work issues is linked to the properties of its framework, which was developed by combining different disciplinary approaches. These methodological choices make it a tool suitable for describing and evaluating the work organization, and get different audiences to think about the development of viable and livable livestock farming systems.

We show that the Work Assessment Method has a wealth of possibilities and can be adapted to a variety of livestock farming contexts throughout the world. However, as suggested by the adaptions to the WAM made by researchers, changes seem to be necessary to better respond to the diversity of work situations found when the research is widened to other productions (work is in progress on horses and bees), other countries, and other forms of agriculture (Hervieu and Purseigle 2013). Present changes in agricultural systems (increasing number of employees, development of local marketing, diversification of farms, agro-ecology, and precision livestock farming) must be taken into account.

The questions about work are increasingly important for devising new livestock systems and accompanying the transition of existing systems to more sustainable forms; hence, there is a strong demand for methods for investigating the organization of work that takes into account recent developments in work, forms of livestock farming, and farmer expectations. Changes to the WAM have to be considered and must propose a simpler and/or modular approach to meet the needs of users. For example, one approach concerns the development of a computer application that can be downloaded, enabling livestock farmers to make a rapid assessment of the routine work on their farm. Questions remain about taking of non-material work, such as the management of paid staff in Uruguay, into account, or the management of information which is developing in precision livestock farming.

The limits of the WAM discussed in this paper point to some possibilities for changing the method. This concerns the articulation of the method with the economic dimension (especially to deal with work productivity), taking into account the sense of the job, the experience of farmers, and the improvement of the farm's flexibility.

\section{Compliance with ethical standards}

Conflict of interest The authors declare that they have no conflict of interest.

\section{References}

Anzalone G, Purseigle F (2014) Délégation d'activités et sous-traitance : au service de la transmission de l'exploitation ou d'un patrimoine? In: Gasselin P, Choisis J-P, Petit S, Purseigle F (eds) L'agriculture en famille : travailler, réinventer, transmettre. EDP Science, Les Ulis, pp 327-338. https://doi.org/10.1051/978-2-7598-1192-2.c018

Aubron C, Cochet H, Brunschwig G, Moulin C-H (2009) Labor and its productivity in Andean dairy farming systems: a comparative approach. Hum Ecol 37:407-419. https://doi.org/10.1007/s10745009-9267-9

Aubron C, Noël L, Lasseur J (2016) Labor as a driver of changes in herd feeding patterns: evidence from a diachronic approach in Mediterranean France and lessons for agroecology. Ecol Econ 127:68-79. https://doi.org/10.1016/j.ecolecon.2016.02.013

Bewley J, Palmer RW, Jackson-Smith DB (2001) Modeling milk production and labor efficiency in modernized Wisconsin dairy herds. J Dairy Sci 84:705-716. https://doi.org/10.3168/jds.S0022-0302(01) 74525-0

Bischoff O, Balard J, Pin A, Chauvat S, Dumonthier P, Serviere G, Dedieu B (2008) L'organisation du travail en élevage. Enseigner la méthode Bilan Travail. Supagro Florac/ INRA/ Institut de l'Elevage, Ed Educagri, Dijon $154 \mathrm{p}$

Bostad E, Swensson C, Pinzke S (2011) Labour input in specialist beef Bull Production in Sweden. Agric Eng Int CIGR J 13(3):21

Cellier J-M, Marquié J-C (1980) Systèmes d'activité et régulations dans l'exploitation agricole. Le Trav Hum 43:321-336

Charroin T, Veysset PP, DEVIENNE S et al (2012) Productivité du travail et économie en élevages d'herbivores : définition des concepts, analyse et enjeux. INRA Prod Anim 25:193-210

Chauvat S, Servière G, Cournut S (2016) Taking into account the meaning, the organization and the productivity of work to better advise farmers transformations in work organization in farms. ISWA Maringa $10 \mathrm{p}$

Cochet H (2015) Controverses sur l'efficacité économique des agricultures familiales : indicateurs pour une comparaison rigoureuse avec d'autres agricultures. Rev Tiers Monde 1:9-25. https://doi.org/10. 3917/rtm.221.0009

Contzen S, Forney J (2017) Family farming and gendered division of labour on the move: a typology of farming-family configurations. Agric Hum Values 34:27-40. https://doi.org/10.1007/s10460-0169687-2

Coquil X, Béguin P, Dedieu B (2014) Transition to self-sufficient mixed crop-dairy farming systems. Renew Agric Food Syst 29:195-205. https://doi.org/10.1017/S1742170513000458

Correa P, Dieguez F, Dedieu B et al (2011) Comprendre l'organisation du travail pour preciser les strategies d'eleveurs laitiers uruguayens. In: Beguin P, Dedieu B, Sabourin E (eds) Le travail en agriculture : son organisation et ses valeurs face a l'innovation. L'Harmattan, Paris, pp $135-153$

Cournut S, Chauvat S (2012) L'organisation du travail en exploitation d'élevage : analyse de 630 Bilans Travail réalisés dans huit filières animales. INRA Prod Anim 25:101-112

Cournut S, Jordan A, Dedieu B, Servière G (2009). Analyse de groupe des Bilans Travail. Guide méthodologique. Document Institut de l'Elevage, http://www.idele.fr

Cournut S, Servière G, Hostiou N et al (2010) L'organisation du travail en exploitations familiales d'élevage. Cah Agric 19:338-347. https:// doi.org/10.1684/agr.2010.0420

Darnhofer I, Bellon S, Dedieu B, Milestad R (2010) Adaptiveness to enhance the sustainability of farming systems. A review. Agron Sustain Dev 30:545-555. https://doi.org/10.1051/agro/2009053

Darnhofer I, Gibbon D, Dedieu B (2012) Farming systems research: an approach to inquiry. In: Farming systems research into the $21 \mathrm{st}$ century: the new dynamic. Springer, Dordrecht, pp 3-31 
Dedieu B, Ingrand S (2010) Incertitude et adaptation : cadres théoriques et application à l'analyse de la dynamique des systèmes d'élevage. INRA Prod Anim 23:81-90

Dedieu B, Servière G (1999) La méthode Bilan Travail et son application. In: Rubino R, Morand-Fehr P (eds) Systems of sheep and goat production: Organization of husbandry and role of extension services, Options Méditerranéennes : Série A. Séminaires Méditerranéens; n. 38. CIHEAM, Zaragoza, pp 353-364 http:// om.ciheam.org/om/pdf/a38/99600177.pdf

Dedieu B, Servière G (2012) Vingt ans de recherche-développement sur le travail en élevage : acquis et perspectives. INRA Prod Anim 25: $85-100$

Dedieu B, Servière G (2016) Changes in work and its organization: the example of livestock farming. 1st International Symposium on Work in agriculture, 8-11 nov 2016 Maringá, Brazil

Dedieu B, Laurent C, Mundler P (1999) Organisation du travail dans les systèmes d'activités complexes [Intérêt et limites de la méthode Bilan Travail]. Économie Rurale 253:28-35. https://doi.org/10. 3406/ecoru.1999.5111

Dedieu B, Chauvat S, Servière G, Tchakerian E (2000) Bilan travail pour l'étude du fonctionnement des exploitations d'élevage : Méthode d'analyse et documents d'enquête. Collection Lignes, Institut de l'Élevage, Paris $27 \mathrm{p}$

Dieguez F (2009) Une expérience de formation au Bilan Travail à distance. 3emes rencontres nationales travail en élevage. http://idele. $\mathrm{fr} /$ ? eID $=$ cmis_download\&oID=workspace://SpacesStore/ 11c61ed0-89b0-42e2-a851-74535a9342a9

Dieguez F, Morales H, Cournut S (2010) La méthode Bilan travail pour l'approche du fonctionnement des élevages extensifs uruguayens. Cah Agric 19:316-322. https://doi.org/10.1684/agr.2010.0419

Dockès AC, Chauvat S, Correa P, Turlot A, Nettle R (2018) Advice and advisory roles about work conditions. An analysis based on case studies in Australia, Belgium, France and Uruguay, to be published in this issue

Dufour A, Dedieu B (2010) Rapports au temps de travail et modes d'organisation en élevage laitier. Cah Agric 19:377-382. https:// doi.org/10.1684/agr.2010.0422

Errington A, Gasson R (1996) The increasing flexibility of the farm and horticultural workforce in England and Wales. J Rural Stud 12:127141. https://doi.org/10.1016/0743-0167(96)00008-3

Fagon J, Sabatte N (2010) Référentiel travail en élevages bovins lait. Synthèse de 190 Bilans Travail. Document Institut de l'Elevage, 36p. http://idele.fr/?eID=cmis_download\&oID=workspace:// SpacesStore/fee677fa-dd92-432b-add7-7aafb9c53a3d

Ferris CP, Frost JC, Binnie RC, Patterson D (2006) Dairy cow performance and labour inputs associated with two silage feeding systems. Grass Forage Sci 61:304-314. https://doi.org/10.1111/j.1365-2494. 2006.00534.x

Fiorelli C, Mouret S, Porcher J (2012) Les rationalités du travail avec les animaux d'élevage : produire, vivre ensemble et se construire. INRA Prod Anim 25:181-192

García-Martínez A, Olaizola A, Bernués A (2009) Trajectories of evolution and drivers of change in European mountain cattle farming systems. Animal 3:152-165. https://doi.org/10.1017/ S1751731108003297

Gibon A, Sibbald AR, Flamant JC, Lhoste P, Revilla R, Rubino R, Sørensen JT (1999) Livestock farming systems research in Europe and its potential contribution for managing towards sustainability in livestock farming. Livest Prod Sci 61:121-137. https://doi.org/10. 1016/S0301-6226(99)00062-7

Gleeson D, O'Brien B, O'Donovan K (2008) The labour input associated with calf care on Irish dairy farms. Livest Sci 116:82-89. https://doi. org/10.1016/j.livsci.2007.08.019

Hemme T, Otte J (2010) Status and prospects for smallholder milk production. A global perspective. FAO, Rome, p 186
Hervieu B, Purseigle F (2013) Sociologie des mondes agricoles, Paris, Armand Colin, coll. U 664 Sociologie, 318 p

Hostiou N, Dedieu B (2012) A method for assessing work productivity and flexibility in livestock farms. Animal 6:852-862. https://doi.org/ 10.1017/S1751731111002084

Hostiou N, Khanh PD, Duteurtre G, Binh VT, Dedieu B (2012) Relationships between work organisation and size of dairy farms: a case study based in Vietnam. Trop Anim Health Prod 44:1709 1716. https://doi.org/10.1007/s11250-012-0128-y

Hostiou N, Cialdella N, Vazquez V, Müller AG, le Gal PY (2015) Work organization on smallholder dairy farms: a process unique to each farm. Trop Anim Health Prod 47:1271-1278. https://doi.org/10. 1007/s11250-015-0859-7

Hostiou N, Fagon J, Chauvat S et al (2017) Impact of precision livestock farming on work and human- animal interactions on dairy farms. A review. Biotechnol Agron Soc Environ 21:1-8

Jafry T, O'Neill DH (2000) The application of ergonomics in rural development: a review. Appl Ergon 31:263-268

Jago J, Eastwood C, Kerrisk K, Yule I (2013) Precision dairy farming in Australasia: adoption, risks and opportunities. Anim Prod Sci 53: 907-916. https://doi.org/10.1071/AN12330

Jean N, Lacroix A, Maamoun M, Mollard A (1988) Durée et intensité du travail des agriculteurs dans la crise économique. Actes et Communications 3:45-82

Jousseins C, Fagon J, Belvèze J, Servière G (2011) Livestock farm networks, a system at the center of French farming development. 9th international rangeland congress, Rosario, Argentina. 117-113. http://remvt.cirad.fr/CD/derniers_num/2015/REMVT15 2-3.pdf

Kling-Eveillard F, Chauvat S, Dedieu B, Servière G, Sabatté S $(2010)$ The "work on livestock farms" network (WLFN): building a new domain of learning and intervention. In Proceedings of the 9th European IFSA Symposium, 1158-1168

Kling-Eveillard F, Cerf M, Chauvat S, Sabatté N (2012) Le travail, sujet intime et multifacette: premières recommandations pour l'aborder dans le conseil en élevage. Prod Anim 25(2):211

Kunda G, Barley SR, Evans J (2002) Why do contractors contract? The experience of highly skilled technical professionals in a contingent labor market. Ind Labor Relat Rev 55:234-261. https://doi.org/10. 2307/2696207

Lacroix A, Mollard A (1991) Mesurer le travail agricole. De l'enregistrement à la reconstitution analytique. Cah d'Econ Sociol Rural 20:27-46

Lallement M, Spurk J (eds) (2003) Stratégies de la comparaison internationale. CNRS Editions, Paris

Lémery B (2003) Les agriculteurs dans la fabrique d'une nouvelle agriculture. Sociol du Trav 45:9-25. https://doi.org/10.1016/S00380296(02)01302-X

Leplat J (1994) Collective activity in work: some ways of research. Le Trav Hum 57:209-226

Madelrieux S, Dedieu B (2008) Qualification and assessment of work organisation in livestock farms. Animal 2:435-446. https://doi.org/ $10.1017 / \mathrm{S} 175173110700122 \mathrm{X}$

Malanski PD, Hostiou N, Ingrand S (2016) Evolution pathways of employees' work on dairy farms according to task content, specialization, and autonomy. Cah Agric 26:1-8. https://doi.org/10.1051/ cagri/2017052

Martel G, Dourmad J-Y, Dedieu B (2008) Do labour productivity and preferences about work load distribution affect reproduction management and performance in pig farms. Livest Sci 116:96-107. https://doi.org/10.1016/j.livsci.2007.09.012

Meul M, Passel S, Fremaut D, Haesaert G (2012) Higher sustainability performance of intensive grazing versus zero-grazing dairy systems. Agron Sustain Dev 32:629-638. https://doi.org/10.1007/s13593011-0074-5

Milestad R, Dedieu B, Darnhofer I, Bellon S (2012) Farms and farmers facing change: the adaptive approach. In: Farming systems research 
into the 21st century: the new dynamic. Springer, Dordrecht, pp 365-385

Morgan-Davies C, Lambe N, Wishart H, Waterhouse T, Kenyon F, McBean D, McCracken D (2018) Impacts of using a precision livestock system targeted approach in mountain sheep flocks. Livest Sci 208:67-76. https://doi.org/10.1016/j.livsci.2017.12.002

Mundler P, Jean-Gagnon J (2017) La productivité du travail dans les exploitations agricoles en circuits courts. 11emes journées de recherches en sciences sociales (JRSS) Lyon Déc 2017. 26 p

Mundler P, Laurent C (2003) Flexibilité du travail en agriculture : méthodes d'observation et évolutions en cours. Ruralia, 12/13. http://ruralia.revues.org/336

Nicholson C, Thornton P, Muinga R (2004) Household-level impacts of dairy cow ownership in coastal Kenya. J Agric Econ 55:175-195. https://doi.org/10.1111/j.1477-9552.2004.tb00092.x

Nozières MO, Moulin CH, Dedieu B (2011) The herd, a source of flexibility for livestock farming systems faced with uncertainties? Animal 5:1442-1457. https://doi.org/10.1017/S1751731111000486

Nye C (2018). The 'blind spot' of agricultural research: Labour flexibility, composition and worker availability in the South West of England. Cah. Agric. 27: 35002. https://doi.org/10.1051/cagri/2018018

O’Donovan K, O'Brien B, Ruane DJ et al (2008) Labour Input on Irish Dairy Farms and the Effect of Scale and Seasonality. J Farm Manag 13:327-342

O'Brien B, O'Donovan K, Gleeson D, Ruane DJ, Kinsella J (2006) Improving labour productivity to facilitate viability on smaller Irish Dairy Farms. J Intern Farm Manag 3(4):19-37

Porcher J (2017) The ethics of animal labor: a collaborative utopia, 2017th edn. Springer International Publishing AG, Cham. https:// doi.org/10.1007/978-3-319-49070-0

Purseigle F, Chouquer G, Collectif (2013) Etudes rurales, $\mathrm{N}^{\circ} 191$ : Les agricultures de firme, vol 2. Délocalisation et évictions. Editions de l'Ecole des Hautes Etudes en Sciences Sociales, Paris

Rault G (2005) Approche sociologique du travail en élevage et questions sur le conseil agricole. Actes du Séminaire de l'Association Française de Production Fourragère « Élevage, prairies, travail », Paris, 20 octobre 2005

Riegel M, Schick M (2007) Working time requirement in agriculturerecording method, model calculation and work budget. Society for Engineering in agriculture. In 2007 National Conference. Agriculture and engineering-challenge today, technology tomorrow, Vol. 23, p. 26

Ryschawy J, Joannon A, Choisis JP, Gibon A, le Gal PY (2014) Participative assessment of innovative technical scenarios for enhancing sustainability of French mixed crop-livestock farms. Agric Syst 129:1-8. https://doi.org/10.1016/j.agsy.2014.05.004

Santos Filho JCD, Hostiou N, Damasceno JC, Dedieu B (2012) Room for manoeuvre in time of the workforce in dairy production systems. Rev Bras Zootec 41(12):2450-2457. https://doi.org/10.1590/ S1516-35982012001200010

Sarzeaud P, Chauvat S (2011) Travibov Démarche de conseil sur le travail en élevage Bovin viande. http://idele.fr/fileadmin/medias/ Documents/11_Conseil_Travibov_29_juin_2011_WEB.pdf

Shreck A, Getz C, Feenstra G (2006) Social sustainability, farm labor, and organic agriculture: findings from an exploratory analysis. Agric Hum Values 23:439-449. https://doi.org/10.1007/s10460-0069016-2

Solano C, León H, Pérez E, Tole L, Fawcett RH, Herrero M (2006) Using farmer decision-making profiles and managerial capacity as predictors of farm management and performance in Costa Rican dairy farms. Agric Syst 88:395-428. https://doi.org/10.1016/j.agsy.2005. 07.003

Sraïri MT, Ghabiyel Y (2017) Coping with the work constraints in croplivestock farming systems. Ann Agric Sci 62:23-32. https://doi.org/ 10.1016/j.aoas.2017.01.001

Sraïri MT, Bahri S, Kuper M (2013) Le travail et sa contribution aux stratégies d'adaptation de petites exploitations agricoles familiales mixtes d'élevage bovin/polyculture au Maroc. Biotechnol Agron Soc Environ 17:463-474

Turlot A (2014) Mise en place de repères pour des exploitations laitières durables en Wallonie. DuraLait Plus, Rapport technique final. Centre de recherches agronomiques, 143p

Turlot A, Froidmont E, Bauraind C, Burny P, Bouquiaux JM, Ledur A, Wavreille J (2013) La dimension" travail", un élément clé pour le maintien de nos systèmes laitiers. 18ème Carrefour des Productions Animales" Nouvelles approches pour une optimisation de nos élevages laitiers", 32-40

Veysset P, Lherm M, Roulenc M, et al (2015) Analyse diachronique de l'efficience technique des systèmes de production bovin viande. Baisse de la productivité des facteurs variables sur 23 ans. Écon Rural:149-169

Veysset P, Lherm M, Boussemart J-P, Natier P (2017) Formation et répartition des gains de productivité en élevage bovin viande. Qui sont les gagnants et les perdants entre 1980 et 2015? Écon Rural:71-91

Weber M (2003) Economie et société, tome 1 : Les Catégories de la sociologie, Nouvelle. Pocket, Paris 